\title{
Application of Process Intensification in the Treatment of Pit Latrine Sludge from Informal Settlements in Blantyre City, Malawi
}

\author{
Khumbo Kalulu ${ }^{1, * \mathbb{C}}$, Bernard Thole ${ }^{2}$, Theresa Mkandawire ${ }^{3}$ and Grant Kululanga ${ }^{3}$ \\ 1 Department of Environmental Health, University of Malawi, Faculty of Applied Sciences, P/Bag 303, \\ Chichiri, Blantyre 3, 312225, Malawi \\ 2 Department of Physics and Biochemical Sciences, University of Malawi, Faculty of Applied Sciences, \\ P/Bag 303, Chichiri, Blantyre 3, 312225, Malawi; bthole@poly.ac.mw \\ 3 Department of Civil Engineering, University of Malawi, Faculty of Engineering, P/Bag 303, Chichiri, \\ Blantyre 3, 312225, Malawi; tmkandawire@poly.ac.mw (T.M.); gkululanga@poly.ac.mw (G.K.) \\ * Correspondence: kkalulu@poly.ac.mw; Tel.:+265-999-691-961
}

Received: 8 March 2020; Accepted: 20 April 2020; Published: 9 May 2020

\begin{abstract}
Many developing countries lack the infrastructure needed for the treatment of fecal sludge. One limitation in implementing available treatment options is the limited availability of land in the urban areas of these countries. This paper investigated the application of process intensification as a way of reducing the land area required to dewater and sanitize pit latrine sludge from informal settlements in Blantyre City, Malawi. The intensification of the sludge treatment process was achieved by enhancing dewatering through the application of additives and by combining the dewatering and sanitization stages. Nine combinations of sludge, lime and rice husk dosages, in addition to a control, were simultaneously loaded on unplanted drying bed units to dewater for 29 days. The study found a significant reduction of $21 \%$ to $73 \%$ in the land area required to dewater and sanitize pit latrine sludge. From the study, process intensification was shown to have the potential to significantly reduce the land area required to dewater and sanitize pit latrine sludge from informal settlements in Malawi cities. This makes it an option that can be implemented close to informal settlements, despite land limitation in these areas.
\end{abstract}

Keywords: dewatering and sanitization; unplanted drying bed; sludge dewatering cycle time; sludge solids loading rate; sustainable sanitation

\section{Introduction}

Many developing countries lack appropriate fecal sludge treatment infrastructure [1,2]. The best method in most countries is to treat fecal sludge in existing centralized wastewater treatment systems, which, in most cases, have dysfunctional equipment and inadequate treatment capacity, leading to an appropriate-to-partial treatment of fecal sludge [3-5]. In addition, most of the centralized wastewater treatment plants are situated far from peri-urban or informal areas where fecal sludge is mostly generated. The foregoing leads to long haulage distances, which are associated with high transportation costs. The extended haulage time and cost to such centralized treatment facilities have been linked to the inability of much of the sludge to reach treatment facilities and end in urban environments in these developing countries [1]. The aforementioned situation still prevails in developing countries, despite the existence of technologies that are deemed to be suitable on the basis of their simplicity, reliability and robustness to shock loads, zero-to-low energy requirement, low skill requirement for operation and maintenance $(\mathrm{O} \& \mathrm{M})$, very low $\mathrm{O} \& \mathrm{M}$ costs, reduced risks associated with system failure and increased reuse opportunities [6]. Such options include unplanted drying beds, 
planted drying beds, co-treatment in waste stabilization ponds, anaerobic pond settling-thickening tanks, constructed wetlands, lime stabilization, co-composting, extended storage and deep row entrenchment $[2,7,8]$. However, most of these require a large area of land to be implemented, which significantly contributes to the capital cost. Such a large area of land is rarely available close to the points of sludge generation. Process intensification provides an opportunity to reduce inputs into the pit latrine sludge treatment. Process intensification is defined as the attainment of a drastic increase in efficiency by using much less to produce much more [9]. Among the targeted outcomes of process intensification are the reduction in capital and running cost, land requirement, time, input materials, energy requirement, waste generation, nuisances, and risk and hazards [10,11]. These outcomes align well with the underlying concepts of sustainable sanitation, Most Appropriate Technology and sustainable sanitation [12-15]. According to Lutze et al. [16], process intensification might be attained through the "integration of unit operations, integration of functions, integration of phenomena and targeted enhancements of phenomena in a given operation". Process intensification has been applied in biodiesel production to reduce long residence times, high operating costs and energy consumption, and low production efficiency [17]. Rao et al. [18] have demonstrated a reduction in the volume of rotating drying beds through process intensification. In membrane engineering, process intensification has been investigated in terms of energy reduction [19]. In wastewater treatment, process intensification has been used to come up with treatment units that are simple to construct and operate, compact, have relatively lower power consumption and lessen waste generation [20,21]. For example, studies such as Pekdemir et al. [20] and Keskinler et al. [21] have applied process intensification for wastewater ferrous iron removal and oxygen transfer, respectively. In fecal sludge treatment, a few studies such as Seck et al. [22] and Gold et al. [23] reflect some form of application of the principles of process intensification. However, most of these investigations have investigated process intensification at the level of targeted enhancement of phenomena within treatment stages in a sequential treatment process. Sitter et al. [24] suggested that such localized intensification leads to weak improvements in the whole process and they advocate for a holistic view when applying process intensification. This paper investigates the extent to which process intensification could lead to a reduction in the land area required to dewater and sanitize pit latrine sludge from informal settlements in Blantyre City, Malawi. Unlike most studies, this research investigation is a combination of the targeted enhancement of phenomena and functional integration forms of process intensification in the sludge treatment process. The study investigated a targeted dewatering of $40 \%$ total solids (TS) and sanitization of $\leq 1000 \mathrm{cfu} / \mathrm{g}$ TS for fecal coliforms and $\leq 3 \mathrm{cfu} / 4 \mathrm{~g}$ TS for Salmonella, as per the World Health Organization's guidelines [25] In assessing land area reduction, this study also investigated the treatment time reduction and sludge solid loading rates that are attainable through the intensification of the pit latrine sludge treatment process.

\section{Materials and Methods}

\subsection{Study Area}

The pit latrine sludge investigated in this study was obtained from latrines in Ndirande Township, the most populous informal settlement in Blantyre City, Malawi [26]. It is also one of the townships where pit latrine emptying has been considerably promoted and adopted.

\subsection{Experimental Design}

The central composite design was used to design treatments of different combinations of lime (L) and rice husks (RH) dosages. This provided nine treatments and a control where no lime or rice husks were added. The selection of the lime dosage range of $10 \%-30 \%$ TS was guided by the range $10 \%-40 \%$ TS documented to be effective in pathogen reduction [27-29]. The dosage of rice husks $(5 \%-15 \%)$ was selected in such a way that so that the proportion of rice husks would not exceed $50 \%$ of the total volume of sludge and additive mixture, so as to ensure that the treatment handles more 
sludge than additives. Table 1 presents the quantities of lime, rice husks and sludge in the treatments and the control.

Table 1. Details of the treatments and control. L: lime; RH: rice husks.

\begin{tabular}{ccccccc}
\hline Treatment & $\begin{array}{c}\text { Lime } \\
\text { Dosage } \\
(\% \text { TS }\end{array}$ & $\begin{array}{c}\text { Rice Husks } \\
\text { Dosage } \\
\text { (\% /TS) }\end{array}$ & $\begin{array}{c}\text { Lime } \\
\text { Quantity } \\
(\mathbf{k g})\end{array}$ & $\begin{array}{c}\text { Rice Husks } \\
\text { Quantity } \\
(\mathbf{k g})\end{array}$ & $\begin{array}{c}\text { Rice Husks } \\
\text { Volume } \\
\text { (L) }\end{array}$ & $\begin{array}{c}\text { Volume of } \\
\text { Sludge } \\
\text { (L) }\end{array}$ \\
\hline $\mathrm{L}_{10}, \mathrm{RH}_{5}$ & 10 & 5 & 3.15 & 1.6 & 14 & 70 \\
$\mathrm{~L}_{10}, \mathrm{RH}_{15}$ & 10 & 15 & 3.15 & 4.7 & 42 & 42 \\
$\mathrm{~L}_{30}, \mathrm{RH}_{15}$ & 30 & 15 & 9.46 & 4.7 & 42 & 42 \\
$\mathrm{~L}_{30}, \mathrm{RH}_{5}$ & 30 & 5 & 9.46 & 1.6 & 14 & 70 \\
$\mathrm{~L}_{6}, \mathrm{RH}_{10}$ & 6 & 10 & 1.89 & 3.2 & 28 & 56 \\
$\mathrm{~L}_{34}, \mathrm{RH}_{10}$ & 34 & 10 & 10.72 & 3.2 & 28 & 56 \\
$\mathrm{~L}_{20}, \mathrm{RH}_{3}$ & 20 & 3 & 6.31 & 0.9 & 8 & 76 \\
$\mathrm{~L}_{20}, \mathrm{RH}_{17}$ & 20 & 17 & 6.31 & 5.4 & 48 & 37 \\
$\mathrm{~L}_{20}, \mathrm{RH}_{10}$ & 20 & 10 & 6.31 & 3.2 & 28 & 56 \\
$\mathrm{C}_{0}$ trol & 0 & 0 & 0 & 0 & 0 & 85 \\
\hline
\end{tabular}

* TS: Total solids.

The values in the table were established from an average of 31.5\% TS and a sludge density of $1200 \mathrm{~kg} / \mathrm{m}^{3}$ from Kalulu et al. [30] and Greya et al. [29]. A rice husk density of $112 \mathrm{~kg} / \mathrm{m}^{3}$ was established in this study.

\subsection{Drying Bed Prototype Design}

The unplanted drying beds in the prototype used in this study were designed based on the typical field configuration recommended in the literature [8,31]. They were designed to accommodate $100 \mathrm{~mm}$-thick layers of coarse gravel, medium gravel and sand and $200 \mathrm{~mm}$ sludge loading depths. Figure 1 shows the prototype, which is made of twelve drying beds.
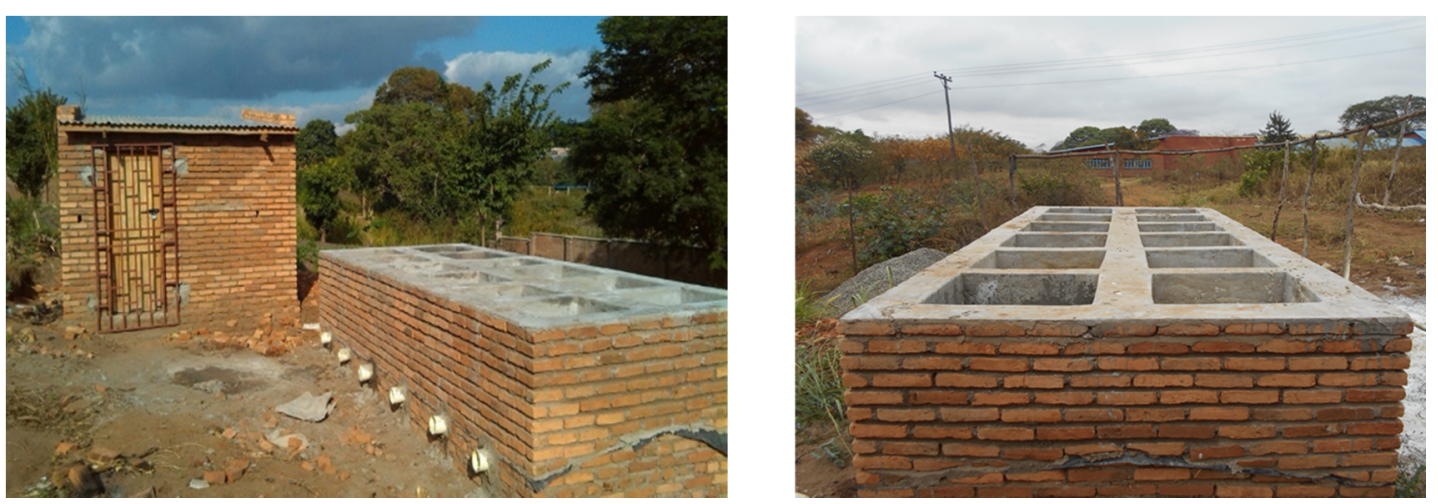

Figure 1. Unplanted drying beds prototype.

The size of the loading surface for each drying bed on the prototype was $0.65 \mathrm{~m} \times 0.65 \mathrm{~m}$. This sizing was done in such a way as to ensure that all the treatments and the control could be loaded from the quantity in a single batch of sludge that is practically manageable to pump in a single day. From the interaction with manual pit emptiers, it was established that emptiers rarely exceed $1 \mathrm{~m}^{3}$ sludge from a single latrine in a day. Based on the $1 \mathrm{~m}^{3}$ sludge requirement, $15 \%$ of sludge volume loss (through removal of non-fecal matter such as plastics and fabrics) during loading and a sludge loading depth of $200 \mathrm{~mm}$, the study came up with the final design of drying beds that had a loading surface of $650 \mathrm{~mm} \times 650 \mathrm{~mm}$. The $15 \%$ for non-fecal matter was chosen as the average of the range of $10 \%-20 \%$ established by Still [32]. Each of the drying beds on the prototype was designed to treat $84.5 \mathrm{~L}$ of treatment sludge at a time. 


\subsection{Loading and Sampling from the Intensified System}

On the prototype, a fixed drying bed was assigned to each treatment and the control. Six cycles of dewatering were run for each of the treatments and the control. The number of cycles/replications was calculated using the one-way ANOVA sample size calculator in Minitab 17. The inputs for the calculations were $80 \%$ power, a sludge-solids loading rate standard deviation of $88.7 \mathrm{~kg} \mathrm{TS} / \mathrm{m}^{2} /$ year and a maximum mean difference of $220 \mathrm{~kg} \mathrm{TS} / \mathrm{m}^{2} /$ year. The maximum mean difference and the standard deviation were established from the solids loading rates reported in studies by Koné et al. [33] and Strande et al. [8]. Each dewatering cycle was 29 days long and consisted of 1 day for sludge loading and 28 days for sludge dewatering. The dewatering time of 4 weeks was chosen as the average of the time range, which was provided by Wang et al. [29], to attain $40 \%$ total solids. For each dewatering cycle, the treatments and control were assigned random numbers, ranging from 1 to 10 . The assigned numbers guided the order of the loading of drying beds on the prototype. The drying bed assigned the number 1 was loaded first and the one assigned the number 10 was loaded last. Sludge samples were collected from the loaded beds for laboratory analyses on day 1 (day of loading), day 15 and day 29 . The loading and sampling of the sludge from the drying bed prototype was done from November 2017 to December 2018. During this period, the atmospheric temperature ranged from $12{ }^{\circ} \mathrm{C}$ to $36^{\circ} \mathrm{C}$. Atmospheric humidity ranged from $11 \%$ to $100 \%$. Wind speed ranged from $0 \mathrm{~km} / \mathrm{hr}$ to $33 \mathrm{~km} / \mathrm{hr}$. During the rainy season, a shed with a light roof and open on the four sides was provided to prevent moisture from getting into the loaded beds and subsequent prolonged dewatering times.

\subsection{Laboratory Analyses}

Laboratory analyses were done to characterize drying bed filter materials, additives (lime and rice husks), raw sludge and sludge mixed with additives. Particle size distribution analysis for drying bed filter materials (sand, medium gravel, and coarse gravel) and additives (lime and rice husks) was done using the sieve analysis method in British Standards, BS 1377 [34]. The determination of rice husk density used the method in Water Research Commission, WRC 2137 [30]. Sludge samples from the treatments and the control were analyzed for $\mathrm{pH}$, biochemical oxygen demand $\left(\mathrm{BOD}_{5}\right)$, chemical oxygen demand (COD), total ammoniacal nitrogen (TAN), density, moisture content (MC), total solids (TS), total volatile solids (TVS), E. coli and Salmonella. For each loading cycle density, $\mathrm{BOD}_{5}, \mathrm{COD}$ and TVS were only analyzed on day 1 of the control sample to get the characteristics of the raw sludge. Analyses of $\mathrm{pH}, \mathrm{TAN}$, moisture content, total solids, density, E. coli and Salmonella were done for all the treatments and the control at the three sampling time points (day 1, day 15 and day 29) in the loading cycle. $\mathrm{pH}$ was analyzed using the potentiometric method [30]. Density was analyzed by the method in WRC 2137 [35]. BOD 5 was analyzed using the titrimetric method in BS 6068: Part 1 [36]. COD was analyzed using the closed reflux titrimetric method [30]. TAN was analyzed using the titrimetric method [30]. Moisture content, total solids and total volatile solids were determined using gravimetric methods [37]. E. coli determination was done using the membrane filtration method [32]. Salmonella analysis was done using the plate count method in Association of Official Analytical Chemists, AOAC [37]. Volumetric concentrations were converted to wet weight concentrations by dividing them by the weight of sludge mixed with distilled water in the parameter analyses. Dry weight concentrations for the parameters were obtained by dividing the wet weight concentrations for samples by their corresponding total solids. All the analyses of the samples were performed in duplicate, and the average values are presented in this study.

\subsection{Data Analysis}

\subsubsection{Sieve Analysis/Particle Size Distribution}

Analyses for particle size distribution for the drying bed filter materials and sludge additives were done using the particle size distribution curves obtained by the sieve analysis method. The percentages of the particles (by mass) less than a given particle size were plotted against the logarithm of the 
effective particle diameter. The distribution of the particle sizes was presented using a three-point specification consisting of $\mathrm{D}_{10}, \mathrm{D}_{50}$, and $\mathrm{D}_{90}$. This specification is considered to be complete and appropriate for most particulate materials [38]. $\mathrm{D}_{10}$ (effective size) is the maximum particle size of the smallest $10 \%$ of the particles. $\mathrm{D}_{50}$ is the sieve diameter through which $50 \%$ of the particles pass and $50 \%$ are retained. $\mathrm{D}_{90}$ describes the sieve diameter through which $90 \%$ of the particles pass and $10 \%$ are retained. The D values were obtained from the intercepts for $10 \%, 50 \%$ and $90 \%$ of the cumulative particle size distribution curves. The uniformity coefficients for the filter media and sludge additives were calculated by dividing $D_{60}$ by the effective size $\left(D_{10}\right)$. $D_{60}$ was obtained from the particle distribution curves of the materials.

\subsubsection{Determination of Sludge Dewatering Cycle Time}

The determination of the sludge dewatering cycle time was based on the target of $40 \%$ total solids attainment in the sludge. This was chosen because it is the higher limit of solids content that is typically achievable through dewatering [2]. The determination of the time required to reach $40 \% \mathrm{TS}$ in each treatment and the control was done using the logarithmic function presented in Equation (1). The logarithmic function was chosen based on the shape of the plots of the total solids against the time obtained in this study, as well as the findings from the studies by Smollen [39] and Seck et al. [22].

$$
\mathrm{TS}=\mathrm{k} \ln \left(\mathrm{t}_{\mathrm{d}}\right)+\mathrm{c}
$$

where TS is total solids (\%), $\mathrm{t}_{\mathrm{d}}$ is the sludge dewatering time (days), and $\mathrm{k}$ and $\mathrm{c}$ are constants.

For each treatment and the control, the constants in the equation were calculated using Microsoft Excel Solver, using the total solids values for day 1, day 15 and day 29. With the constants determined, the Goal Seek function in Microsoft Excel was used to calculate the dewatering time for the treatments and the control to reach $40 \%$ TS. For each of the treatments and the control, the sludge dewatering cycle time was calculated using Equation (2).

$$
t_{d c}=t_{L}+t_{d}+t_{s r}
$$

where $t_{d c}$ is sludge dewatering cycle time (days), $t_{L}$ is the sludge loading time (days), $t_{d}$ is the sludge dewatering time (days) and $t_{s r}$ is the sludge removal time (days).

One-way ANOVA with Dunnett's post hoc was used to compare the means of the treatments and the control for significant differences in the dewatering cycle time among the treatments and the control.

\subsubsection{Determination of Sludge Solids Loading Rates}

Using the dewatering cycle times calculated from Equation (2), the solids loading rates for the treatments and the control were calculated using Equation (3).

$$
S L R_{s}=\frac{V_{s} * D_{s} * T S_{i} * 365}{t_{d c} * A * 100}
$$

where $S L R_{S}$ is the sludge solids loading rate $\left(\mathrm{kg} / \mathrm{m}^{2} / \mathrm{yr}\right), V_{S}$ is the volume of the applied sludge $\left(\mathrm{m}^{3}\right)$, $D_{s}$ is the density of raw sludge $\left(\mathrm{kg} / \mathrm{m}^{3}\right), T S_{i}$ is the sludge initial solids content $(\%), t_{d c}$ is the sludge dewatering cycle time to reach $40 \%$ TS (days), and $A$ is the sludge loading surface area $\left(\mathrm{m}^{2}\right)$.

One-way ANOVA with Dunnett's post hoc was used to assess significant differences in the sludge solids loading rates in the treatments and the control.

\subsubsection{Treatment Land Area Requirement Reduction}

The reduction in the land area requirement for each of the treatments, relative to the control, was calculated using Equation (4). 


$$
\text { Land area reduction }(\%)=\left(1-\left(\frac{\text { Control solids loading rate }}{\text { Treatment solids loading rate }}\right)\right) * 100
$$

\subsection{Ethical Approval}

Ethical approval (no. P11/17/231) was obtained for the study from the National Commission of Science and Technology (NCST).

\section{Results}

\subsection{Drying Bed Filter Material Characteristics}

The effective size $\left(D_{10}\right)$ of the sand used in the drying bed was $0.25 \mathrm{~mm}$. The $D_{50}$ and $D_{90}$ values for the sand were $0.53 \mathrm{~mm}$ and $1.6 \mathrm{~mm}$, respectively. The $\mathrm{D}_{60}$ value for the sand was $0.6 \mathrm{~mm}$. The uniformity coefficient $\left(C_{u}\right)$ for the sand was 2.4. The $D_{10}$ of the medium gravel used in the middle layer of the drying bed filter unit was $5.2 \mathrm{~mm}$. The $D_{50}$ and $D_{90}$ values for the middle layer gravel were $7 \mathrm{~mm}$ and $9.2 \mathrm{~mm}$, respectively. The $D_{60}$ value for the middle layer gravel was $7.5 \mathrm{~mm}$. The $C_{u}$ for the middle layer gravel was 1.44. The $\mathrm{D}_{10}$ of the coarse gravel used in the bottom layer of the drying bed was $8.5 \mathrm{~mm}$. The $D_{50}$ and $D_{90}$ values for the bottom layer gravel were $15.5 \mathrm{~mm}$ and $19 \mathrm{~mm}$, respectively. The $D_{60}$ value for the bottom layer gravel was $16 \mathrm{~mm}$. The value of the $C_{u}$ for the bottom layer gravel was 1.88 .

\subsection{Sludge Additives Characteristics}

The $\mathrm{D}_{10}$ of the rice husks was $0.9 \mathrm{~mm}$. The $\mathrm{D}_{50}$ and $\mathrm{D}_{90}$ values for the rice husks were $1.7 \mathrm{~mm}$ and $2.4 \mathrm{~mm}$, respectively. The $\mathrm{D}_{60}$ value for the rice husks was $1.8 \mathrm{~mm}$. The $\mathrm{C}_{\mathrm{u}}$ for the rice husks was 2. For lime, about $84 \%$ of the mass of the lime passed through the smallest sieve size of $0.038 \mathrm{~mm}$ used in this study. As such, it was not possible to determine the $D_{10}, D_{50}$ and $D_{60}$ values for the lime. The $\mathrm{D}_{90}$ value for the lime was $0.05 \mathrm{~mm}$.

\subsection{Raw Sludge Characteristics}

Table 2 presents the characteristics of the raw pit latrine sludge used in the process intensification study. $\mathrm{BOD}_{5}$ concentration ranged from $7452 \mathrm{mg} / \mathrm{L}$ to $15,653 \mathrm{mg} / \mathrm{L}$, with a mean value of $11,107 \mathrm{mg} / \mathrm{L}$. COD concentration ranged from $56,640 \mathrm{mg} / \mathrm{L}$ to $168,000 \mathrm{mg} / \mathrm{L}$, with a mean value of $105,984 \mathrm{mg} / \mathrm{L}$. The TAN concentration ranged from $139 \mathrm{mg} / \mathrm{L}$ to $201 \mathrm{mg} / \mathrm{L}$, with a mean value of $170 \mathrm{mg} / \mathrm{L}$. The dry weight concentration of TAN ranged from $0.9 \mathrm{mg} / \mathrm{g}$ TS to $3.4 \mathrm{mg} / \mathrm{g}$ TS, with a mean of $1.5 \mathrm{mg} / \mathrm{g}$ TS.

Table 2. Summary statistics of raw sludge characteristics. BOD: biochemical oxygen demand; COD: chemical oxygen demand; TAN: total ammoniacal nitrogen; MC: moisture content; TS: total solids; TVS: total volatile solids.

\begin{tabular}{cccc}
\hline Parameter & Mean & Min & Max \\
\hline $\mathrm{pH}$ & 8.3 & 8.0 & 9.0 \\
Density $\left(\mathrm{kg} / \mathrm{m}^{3}\right)$ & 1107 & 1085 & 1115 \\
BOD $_{5}(\mathrm{mg} / \mathrm{l})$ & 11,107 & 7452 & 15,653 \\
COD $(\mathrm{mg} / \mathrm{l})$ & 105,984 & 56,640 & 168,000 \\
TAN $(\mathrm{mg} / \mathrm{g} \mathrm{TS})$ & 1.5 & 0.9 & 3.4 \\
MC $(\%)$ & 85.3 & 77.5 & 94.7 \\
TS $(\%)$ & 14.7 & 5.3 & 22.5 \\
TVS (mg/g TS) & 506 & 452 & 540 \\
E. coli $(\mathrm{cfu} / \mathrm{g} \mathrm{TS})$ & 584,182 & 160,780 & $1,504,514$ \\
Salmonella $(\mathrm{cfu} / \mathrm{g}$ TS) & 1659 & 80 & 3134 \\
\hline
\end{tabular}




\section{4. $p H$ in Treatments and Control}

On day 1 , the mean $\mathrm{pH}$ in the control $(8.3 \pm 0.2)$ was lower than the means for the treatments, which ranged from $11.4 \pm 0.1$ to $13.8 \pm 0.1$. On day 15 , the mean $\mathrm{pH}$ value in the control $(7.9 \pm 0.1)$ was also lower than the mean values for the treatments, which ranged from $10.4 \pm 0.7$ to $13.7 \pm 0.1$. On day 29 , the mean $\mathrm{pH}$ value in the control $(8.0 \pm 0.2)$ was lower than the mean values for the treatments, which ranged from $10.8 \pm 0.4$ to $13.8 \pm 0.1$.

\subsection{Total Ammoniacal Nitrogen}

On day 1 , the mean TAN in the treatments and control ranged from $0.42 \pm 0.06 \mathrm{mg} / \mathrm{g}$ TS to $1.53 \pm 0.4 \mathrm{mg} / \mathrm{g}$ TS. On day 15 , the mean TAN in the treatments and control ranged from $0.32 \pm 0.08 \mathrm{mg} / \mathrm{g}$ TS to $0.66 \pm 0.17 \mathrm{mg} / \mathrm{g}$ TS. On day 29 , the mean TAN in the treatments and control ranged from $0.22 \pm 0.04 \mathrm{mg} / \mathrm{g}$ TS to $0.46 \pm 0.12 \mathrm{mg} / \mathrm{g}$ TS.

\subsection{Moisture Content}

On day 1 , the average moisture content in the control $(85.3 \pm 2.4 \%)$ was higher than the treatment, with the moisture content ranging from $62.9 \pm 1.5 \%$ to $83.6 \pm 1.4 \%$. For day 15 , the average moisture content in the control and treatments ranged from $51.9 \pm 1.3 \%$ to $69.5 \pm 2.1 \%$. On day 29 , the average moisture content in the control and treatments ranged from $44.3 \pm 2.1 \%$ to $57.2 \pm 2.2 \%$.

\subsection{Total Solids}

On day 1 , the average TS in the control $(14.7 \pm 2.4 \%)$ was lower than the treatment, with the average TS ranging from $16.4 \pm 1.4 \%$ to $37.1 \pm 1.5 \%$. For day 15 , the average TS in the control and treatments ranged from $30.5 \pm 2.1 \%$ to $48.1 \pm 1.3 \%$. On day 29 , the average TS in the control and treatments ranged from $42.8 \pm 2.2 \%$ to $55.7 \pm 2.1 \%$.

\subsection{E. coli}

For all three sampling days, the study found $E$. coli in two treatments $\left(\mathrm{L}_{10}, \mathrm{RH}_{5}\right.$ and $\left.\mathrm{L}_{6}, \mathrm{RH}_{10}\right)$ and the control. On day 1 , the mean E. coli concentrations in the treatments $\mathrm{L}_{10}, \mathrm{RH}_{5}$ and $\mathrm{L}_{6}, \mathrm{RH}_{10} \mathrm{were}$ $125,367 \pm 62,092 \mathrm{cfu} / \mathrm{g}$ TS and 251,551 $\pm 105,845 \mathrm{cfu} / \mathrm{g}$ TS, respectively. The mean E. coli concentration in the control was $584,182 \pm 208,465 \mathrm{cfu} / \mathrm{g}$ TS. On day 15 , the E. coli concentrations in treatments $\mathrm{L}_{10}$, $\mathrm{RH}_{5}$ and $\mathrm{L}_{6}, \mathrm{RH}_{10}$ were 35,372 $\pm 15,831 \mathrm{cfu} / \mathrm{g}$ TS and 69,788 $\pm 26,568 \mathrm{cfu} / \mathrm{g}$ TS, respectively. The mean E. coli concentration in the control was $164,221 \pm 56,266 \mathrm{cfu} / \mathrm{g}$ TS. On day 29 , the E. coli concentrations in the treatments $\mathrm{L}_{10}, \mathrm{RH}_{5}$ and $\mathrm{L}_{6}, \mathrm{RH}_{10}$ were $23,712 \pm 8074 \mathrm{cfu} / \mathrm{g}$ TS and 50,628 $\pm 14,663 \mathrm{cfu} / \mathrm{g}$ TS, respectively. The mean $E$. coli concentration in the control was $62,552 \pm 11,968 \mathrm{cfu} / \mathrm{g}$ TS.

\subsection{Salmonella}

The study found Salmonella in three treatments $\left(\mathrm{L}_{10}, \mathrm{RH}_{5} ; \mathrm{L}_{10}, \mathrm{RH}_{15}\right.$ and $\left.\mathrm{L}_{6}, \mathrm{RH}_{10}\right)$ and the control at all three sampling times. On day 1, the mean Salmonella concentrations were $210 \pm 210 \mathrm{cfu} / \mathrm{g}$ TS for treatment $\mathrm{L}_{10}, \mathrm{RH}_{5} ; 316 \pm 316 \mathrm{cfu} / \mathrm{g}$ TS for treatment $\mathrm{L}_{10}, \mathrm{RH}_{15} ; 304 \pm 304 \mathrm{cfu} / \mathrm{g}$ TS for treatment $\mathrm{L}_{6}$, $\mathrm{RH}_{10}$; and $1659 \pm 518 \mathrm{cfu} / \mathrm{g}$ TS for the control. On day 15, the mean Salmonella concentrations were $85 \pm 85 \mathrm{cfu} / \mathrm{g}$ TS for treatment $\mathrm{L}_{10}, \mathrm{RH}_{5} ; 80 \pm 80 \mathrm{cfu} / \mathrm{g}$ TS for treatment $\mathrm{L}_{10}, \mathrm{RH}_{15} ; 152 \pm 152 \mathrm{cfu} / \mathrm{g}$ TS for treatment $\mathrm{L}_{6}, \mathrm{RH}_{10}$; and $600 \pm 77 \mathrm{cfu} / \mathrm{g}$ TS for the control. On day 29, the mean Salmonella concentrations were $80 \pm 80 \mathrm{cfu} / \mathrm{g}$ TS for treatment $\mathrm{L}_{10}, \mathrm{RH}_{5} ; 36 \pm 36 \mathrm{cfu} / \mathrm{g}$ TS for treatment $\mathrm{L}_{10}, \mathrm{RH}_{15}$; $41 \pm 41 \mathrm{cfu} / \mathrm{g}$ TS for treatment $\mathrm{L}_{6}, \mathrm{RH}_{10}$; and $336 \pm 33 \mathrm{cfu} / \mathrm{g}$ TS for the control.

\subsection{Sludge Dewatering Cycle Time}

Figure 2 shows the mean dewatering cycle times to attain $40 \%$ TS for the six replicates of the treatments and the control. The mean dewatering cycle times in the treatments and the control ranged from 5.5 days to 53 days. 


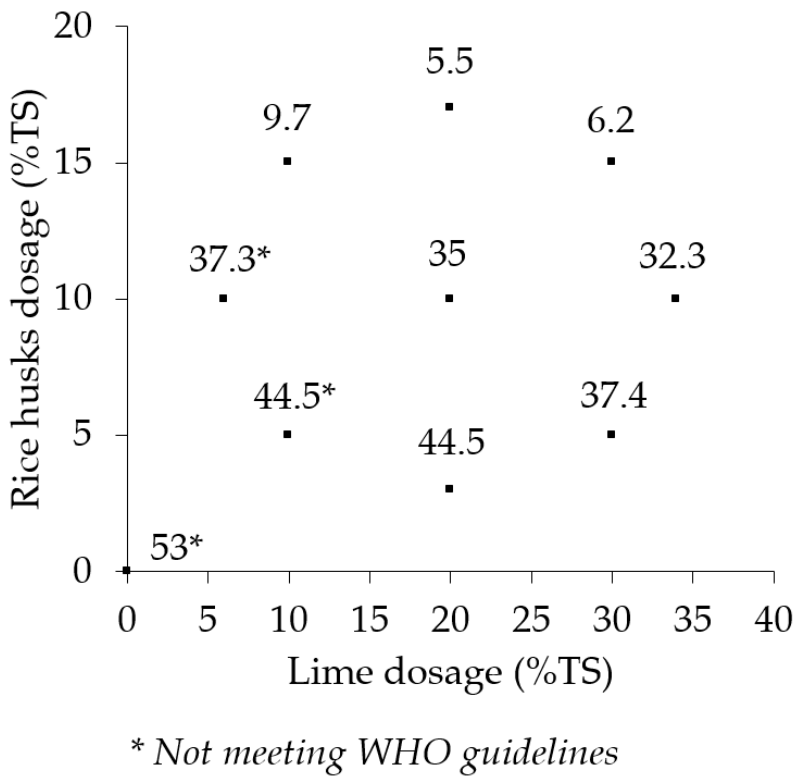

Figure 2. Sludge dewatering cycle time (in days) for the treatments and the control. WHO: World Health Organization.

A one-way ANOVA test showed a significant difference in the mean dewatering cycle times in the treatments and the control $(\mathrm{F}(9,50)=3.2, p=0.004)$. A Dunnett's post hoc test revealed that treatments $\mathrm{L}_{30}, \mathrm{RH}_{15}$ (6.2 days), $\mathrm{L}_{20}, \mathrm{RH}_{17}$ (5.5 days) and $\mathrm{L}_{10}, \mathrm{RH}_{15}$ (6.2 days) had significantly shorter dewatering cycle times than the rest of the treatments and the control. The mean dewatering cycle times for the rest of the treatments ranged from 9.7 days to 44.5 days. The mean dewatering time for the control was 53 days. There was no statistically significant difference in the mean dewatering cycle times in the control and the other seven treatments.

\subsection{Sludge Solids Loading Rates}

Figure 3 shows mean sludge solids loading rates from the six replications of the treatments and the control. The mean sludge solids loading rates among the treatments and control ranged from $286 \mathrm{~kg} \mathrm{TS} / \mathrm{m}^{2} /$ year to $1043 \mathrm{~kg} \mathrm{TS} / \mathrm{m}^{2} /$ year.

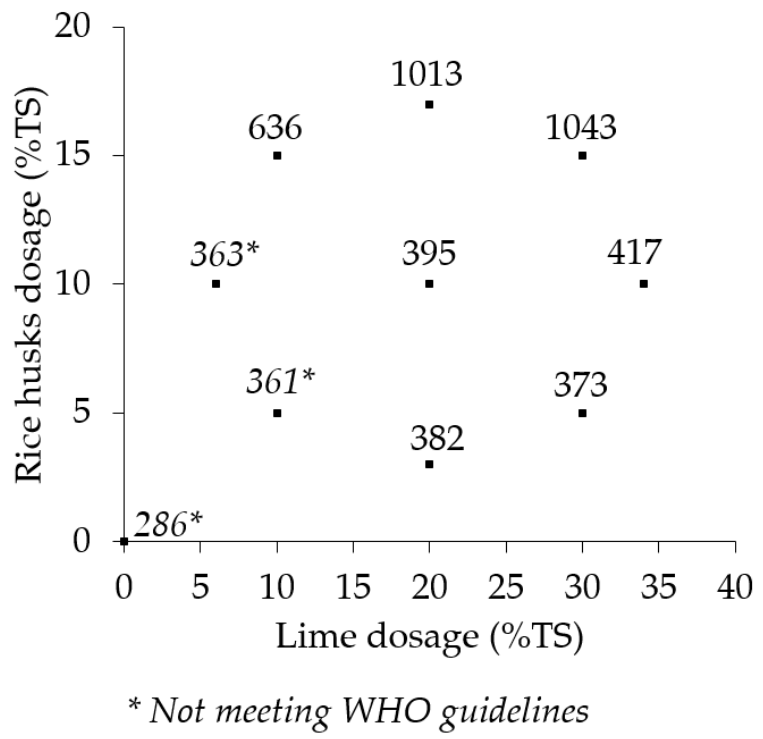

Figure 3. Sludge solids loading rates (in $\mathrm{kg} \mathrm{TS} / \mathrm{m}^{2} /$ year) in the treatments and control. 
A one-way ANOVA showed a significant difference in the mean sudge solids loading rates $(\mathrm{F}(9,50)=3.7, p=0.001)$ of the treatments and the control. A Dunnett's post hoc test revealed that the sludge solids loading rates for treatments $\mathrm{L}_{30}, \mathrm{RH}_{15}\left(1043 \mathrm{~kg} \mathrm{TS} / \mathrm{m}^{2} /\right.$ year$)$ and $\mathrm{L}_{20}, \mathrm{RH}_{17}$ (1013 kg TS/m²/year) were significantly higher than the rest of the treatments and the control. The mean sludge solids loading rates for the rest of the treatments and the control ranged from $286 \mathrm{~kg} \mathrm{TS} / \mathrm{m}^{2} /$ year to $636 \mathrm{~kg} \mathrm{TS} / \mathrm{m}^{2} /$ year. There was no statistically significant difference in the mean solids loading rates of the control and the other seven treatments.

\subsection{Treatment Land Area Requirement Reduction}

Figure 4 shows the mean percentage land area requirement reduction that the treatments would achieve in order to treat the same mass of solids in the same time as the control. The mean land area requirement reductions were established from six replications of the treatments and the control. The land area reductions resulting from the addition of lime and rice husks to the sludge ranged from $21 \%$ in treatment $\mathrm{L}_{10}$ and $\mathrm{RH}_{5}$ to $73 \%$ in treatments $\mathrm{L}_{30}$ and $\mathrm{RH}_{15}$.

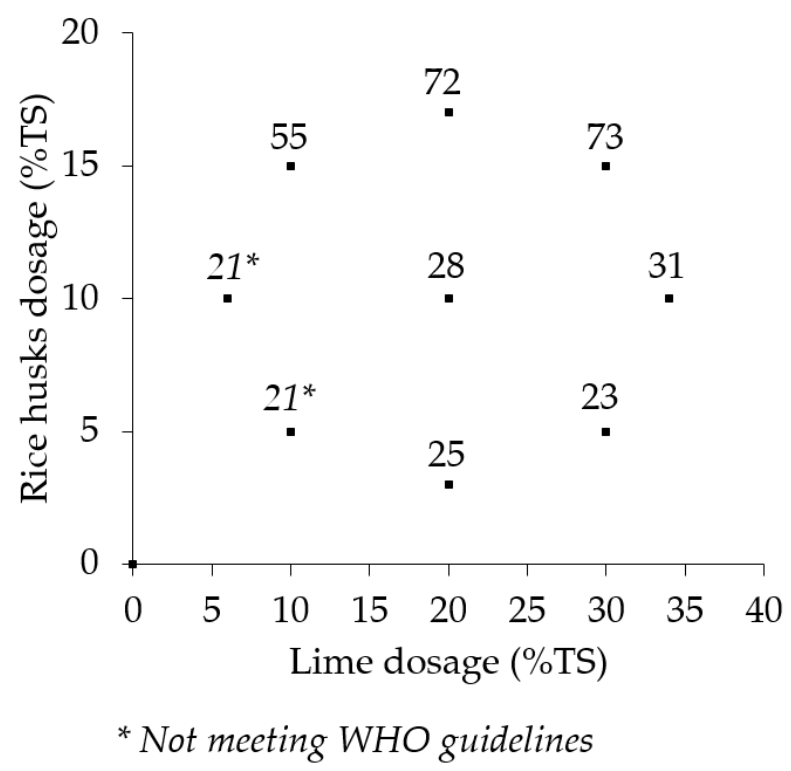

Figure 4. Percentage land area requirement reduction relative to the control.

\section{Discussion}

\subsection{Physical and Hydraulic Characteristics of the Intensified System Materials}

The bulk density of rice husks of $112 \mathrm{~kg} / \mathrm{m}^{3}$ established in this study was comparable to the range of $90-110 \mathrm{~kg} / \mathrm{m}^{3}$, which is presented in the literature [2]. The uniformity coefficients for the filter material, i.e., sand (2.4), middle layer medium gravel (1.44) and bottom layer coarse gravel (1.88) and rice husks (2), were within the recommended value of less than four for effective dewatering in a filter configuration. Values of the uniformity coefficient above four lead to abrupt changes in the hydraulic conductivity of the filter and promote subsurface pore clogging in the filter [40].

\subsection{Total Time to Attain Dewatering and Sanitization}

In this study, one rationale for the intensification of the sludge treatment process was that the intensification would lead to a reduction in the total time required to dewater and sanitize pit latrine sludge. The sanitization target in this study was to attain $\leq 1000 \mathrm{cfu} / \mathrm{g}$ TS for fecal coliforms and $\leq 3 \mathrm{cfu} / 4 \mathrm{~g}$ TS for Salmonella as recommended by the World Health Organization [25]. Except for three treatments $\left(\mathrm{L}_{10}, \mathrm{RH}_{5} ; \mathrm{L}_{10}, \mathrm{RH}_{15}\right.$ and $\left.\mathrm{L}_{6}, \mathrm{RH}_{10}\right)$ and the control, all the treatments had pathogen concentrations that met the World Health Organization's recommendation by the time they reached 
$40 \%$ TS. Unlike the other treatments, these three treatments and the control had average $\mathrm{pH}$ values of less than 12 at all sampling times. Based on the treatments investigated in this study, a lime dosage of $20 \%$ TS was found to be the minimum required to attain sanitization. The $20 \%$ TS dosage is higher than the $10 \%$ TS that Abu-Orf et al. [28] found, and within the range of 10\%-35\% TS found by Greya et al. [29]. One possible explanation for these different results might be the differences in the levels of mixing done for the sludge and lime. Abu-Orf et al. [28] and Greya et al. [29], for example, used mixers to attain homogeneity, unlike manual mixing, which was employed in this study. It is highly probable that a higher quantity of lime was needed to make sure that it was uniformly distributed throughout the sludge-additive mixture in this study. In addition, although other studies have found ammonia to be key in pathogen die-off, the findings from this study tend to show that ammonia may not have been the major contributor to pathogen die-off as the total ammoniacal nitrogen concentrations established did not vary much among the treatments and the control at three sampling times within the cycles and throughout the sampling cycles. In some cases, pathogen die-off may, to a lesser extent, be attributed to a low moisture content, which fell below the minimum 50\% that Bakare et al. [4] stated to be adequate for microbial activity.

The findings of the study demonstrate that the intensified system has the potential to reduce on time in order to attain both dewatering and sanitation. In this study, the total treatment time to attain these two objectives was found to be shorter than the time that it took the control to attain $40 \%$ total solids dewatering alone. The dewatering time of 53 days established for the unconditioned sludge in the control in this study was higher than the dewatering times reported on unconditioned sludge in the literature. Wang et al. [41], for example, reported dewatering times in the range of 14 days to 42 days to attain $40 \%-45 \%$ total solids. Seck et al. [22] found dewatering times ranging from 8 days to 12 days. The shorter dewatering times in these studies may be due to a higher level of stabilization in the sludge they investigated, which may have led to a higher dewaterability than the sludge in this study. Another possible explanation for the difference may be the smaller loading depths and lower sludge solids loading rates (in the range of $100 \mathrm{~kg} \mathrm{TS} / \mathrm{m}^{2} /$ year to $150 \mathrm{~kg} \mathrm{TS} / \mathrm{m}^{2} /$ year) that were investigated by Seck et al. [22]. However, a study by Kuffour et al. [42] found similarly shorter dewatering times, which ranged from four days to seven days for unconditioned sludge, despite having a similar sludge loading depth of $200 \mathrm{~mm}$, as was the case in this study. The shorter drying time might have resulted from a lower total solid target during dewatering. In the study by Kuffour et al. [42], the dewatering cycle ran up to the time when the sludge had become spadable and stopped producing percolate, which in most cases is within the range of $20 \%-25 \%$ TS.

While the treatment times found in this study are comparatively similar to the dewatering times in the control and other studies where the process was not intensified, it should be kept in mind that the treatment time in this study covers both dewatering and sanitization. The difference between the treatments and the control in this study, therefore, provides a picture of the minimum time that could be saved from the treatments that were investigated in this study. Factoring in the additional time required for the sanitization of dewatered sludge from the control in this study would likely lead to a longer total treatment time. The additional time would range from days to years, depending on the sanitization option chosen. Compared to the maximum of 44.5 days established in this study, it would take more than six months to attain the targeted dewatering and sanitization through extended storage $[43,44]$. Composting would require a minimum of 58 days to attain the targeted dewatering and sanitization levels, based on a time requirement of 5 days to 15 days, for composting, as reported by Tayler [2].

\subsection{Sludge Solids Loading Rates}

The design of the study theorized that shortening the dewatering cycle time through process intensification would lead to an increased sludge loading frequency and a resulting increase in the sludge quantity treated in a unit bed area in a given time. The findings of this study demonstrate that higher sludge solids loading rates were attainable through the intensification of the fecal sludge 
treatment process. All treatments investigated in this study had higher sludge solids loading rates than the control. The sludge solids loading rate $\left(286 \mathrm{~kg} \mathrm{TS} / \mathrm{m}^{2} / \mathrm{year}\right)$, established for the control in this study, falls within the range of $50 \mathrm{~kg} \mathrm{TS} / \mathrm{m}^{2} /$ year to $420 \mathrm{~kg} \mathrm{TS} / \mathrm{m}^{2} /$ year, which was reported for unconditioned sludge in the literature [8,45]. The sludge solids loading rates range for the treatments in this study $\left(361 \mathrm{~kg} \mathrm{TS} / \mathrm{m}^{2} /\right.$ year to $1043 \mathrm{~kg} \mathrm{TS} / \mathrm{m}^{2} /$ year) was lower than the range of $505 \mathrm{~kg} \mathrm{TS} / \mathrm{m}^{2} /$ year to $1239 \mathrm{~kg} \mathrm{TS} / \mathrm{m}^{2} /$ year, which was established in a study by Kuffour [46]. In his study, he conditioned sludge with different dosages of sawdust and loaded to a similar depth of $200 \mathrm{~mm}$ on drying bed columns. One possible explanation for the lower range of sludge solids loading rates in this study could be the longer dewatering cycle times required to attain a higher dewatering target of $40 \%$ total solids, in comparison to the $20 \%-25 \%$ TS dewatering target by Kuffour [44]. Dewatering cycle time is used when calculating the sludge solids loading rates and holding loading depth, sludge density, total solids concentration and loading area constant-the shorter the dewatering cycle time, the higher the sludge solids loading rates, as more loading cycles are achievable in a given time.

\subsection{Treatment Land Area Requirement Reduction}

The major underlying hypothesis for the process intensification study was that it was possible to reduce the total land area that is required to treat pit latrine sludge from informal settlements in Malawi cities. This study demonstrates that process intensification has the potential to lead to significant reductions in the land area required to dewater and sanitize pit latrine sludge. The treatment land area reduction range (21\% to $73 \%$ ) was slightly lower than the range of $59 \%-97 \%$ reduction in the drying bed area established in a study by Gold et al. [23]. This difference may be due to the lower dewaterability of the pit latrine sludge used in this study, in comparison to the more stabilized septage conditioned by Gold et al. [23]. The differences in the dewaterability may also arise from the difference in the levels of mixing and homogeneity of the conditioner-sludge mixtures. Considering the small volumes that were thoroughly mixed in jars by Gold et al. [20], it is highly likely that the sludge-conditioner mixture was more homogeneous in comparison to this study in which about $84 \mathrm{~L}$ of sludge and conditioners were mixed manually. In the study by Gold et al. [23], the larger reduction in land area requirement could have resulted from the shorter time required to attain the dewatering target for composting, which Koné et al. [32] presented as 20\% TS. It is highly probable that targeting $40 \%$ TS dewatering in their study may have resulted in longer dewatering times and corresponding smaller land area reductions. As with the dewatering cycle time, the range of land area requirement reduction attained in the different treatments, relative to the control, represents the minimum reductions to achieve dewatering and sanitization. Reductions of larger magnitudes are likely to be attainable if the land area required to sanitize the dewatered unconditioned sludge was considered.

The reduction in land area requirement for dewatering and sanitization achieved in this study demonstrates that the intensified system provides a sludge treatment option that has potential to be implemented closer to the informal settlements where pit latrine sludge is generated and land availability is limited. The shorter distances achieved by having such systems closer to points of sludge generation could significantly reduce the haulage distance between the point of generation and treatment. According to Taweesan et al. [1] shorter distances may imply a reduction in haulage time and cost, with an increased likelihood of getting more sludge reaching treatment facilities. Since transportation costs constitute the major cost in the fecal sludge management chain, the reduction of this cost may translate to a significant reduction in the cost of the different services in the chain and could make the services affordable to more onsite sanitation users in informal settlements. This has the potential to decrease the improper disposal of pit latrine sludge into urban environments and an associated reduction in the public and environmental health risks associated with the sludge being in urban areas of developing countries. A reduced distance has the potential to lead to lower fuel usage and lower vehicle maintenance costs. In addition, this also has the potential to reduce the carbon footprint that arises from the haulage of sludge for treatment, disposal and reuse. In addition, the use 
of a substitute material, where rice husks are not readily available, provides an opportunity to address the challenge of some of the biodegradable solid wastes in Malawi cities.

\section{Conclusions}

This study demonstrates that the application of process intensification (lime and rice husk dosing) in the treatment of pit latrine sludge has the potential to lead to a significant reduction in the time or land area required to dewater and sanitize pit latrine sludge from informal settlements in Malawi cities. This makes the intensified system an option that can be implemented close to the informal settlements with limited available land. There is a need to investigate the intensification of the sludge treatment process in terms of all three treatment objectives of dewatering, sanitization and stabilization. Materials such as locally made activated carbon could be included as one of the additives, or a layer in the filter system to enhance the stabilization of organics. Future studies on the intensification of the pit latrine sludge treatment process should consider the lime dosage range of $20 \%-30 \%$ TS and a rice husks dosage range of $15 \%-17 \%$ TS as the best guess and to pick other treatments around these levels.

Author Contributions: This work was carried out as part of K.K.'s PhD study. K.K. was involved in conceptualization, methodology, data analysis, manuscript preparation and funding acquisition. B.T. was involved in conceptualization, manuscript review and editing, and supervision. T.M. was involved in conceptualization, manuscript review and editing, and supervision. G.K. was involved in conceptualization, manuscript review and editing, and supervision. All authors have read and agreed to the published version of the manuscript.

Funding: This research was funded by the Consortium for Advanced Research Training in Africa (CARTA).

Acknowledgments: This research was supported by the Consortium for Advanced Research Training in Africa (CARTA). CARTA is jointly led by the Africa Population and Health Research Center and the University of the Witwatersrand and funded by the Carnegie Corporation of New York (Grant No-B 8606.R02), Sida (Grant No: 54100113), the DELTAS Africa Initiative (Grant No: 107768/Z/15/Z) and Deutscher Akademischer Austauschdienst (DAAD). The DELTAS Africa Initiative is an independent funding scheme of the African Academy of Sciences (AAS)'s Alliance for Accelerating Excellence in Science in Africa (AESA) and supported by the New Partnership for Africa's Development Planning and Coordinating Agency (NEPAD Agency) with funding from the Wellcome Trust (UK) and the UK government. The statements made and views expressed are solely the responsibility of the Fellow. The authors would also like to acknowledge the support from the team of laboratory technicians from The University of Malawi in the Faculty of Applied Sciences for carrying out the analyses.

Conflicts of Interest: The authors declare no conflict of interest. The funders played no role in the study design, data collection, analyses or interpretation, manuscript writing, or in the decision to publish the results.

\section{References}

1. Taweesan, A.; Koottatep, T.; Dongo, K. Factors influencing the performance of faecal sludge management services: Case study in Thailand municipalities. Environ. Dev. Sustain. 2017, 19, 125-140. [CrossRef]

2. Tayler, K. Faecal Sludge and Septage Treatment: A Guide for Low and Middle Income Countries; Practical Action Publishing: Rugby, UK, 2018.

3. Massoud, M.A.; Tarhini, A.; Nasr, J.A. Decentralized approaches to wastewater treatment and management: Applicability in developing countries. J. Environ. Manag. 2009, 90, 652-659. [CrossRef]

4. Bakare, B.F.; Foxon, K.M.; Brouckaert, C.J.; Buckley, C.A. Variation in VIP latrine sludge contents. Water $S A$ 2012, 38, 479-486. [CrossRef]

5. Blackett, I.; Hawkins, P.; Heymans, C. The Missing Link in Sanitation Service Delivery: A Review of Fecal Sludge Management in 12 Cities; WSP-World Bank Research Brief: Washington, DC, USA, 2014.

6. Singh, S.; Haberl, R.; Moog, O.; Shrestha, R.R.; Shrestha, P.; Shrestha, R. Performance of an anaerobic baffled reactor and hybrid constructed wetland treating high-strength wastewater in Nepal-A model for DEWATS. Ecol. Eng. 2009, 35, 654-660. [CrossRef]

7. Strauss, M.; Larmie, S.A.; Heinss, U. Treatment of sludges from on-site sanitation-Low-cost options. Water Sci. Technol. 1997, 35, 129-136. [CrossRef]

8. Strande, L.; Brdjanovic, D. Faecal Sludge Management: Systems Approach for Implementation and Operation; IWA Publishing: London, UK, 2014.

9. Coward, T.; Tribe, H.; Harvey, A.P. Opportunities for process intensification in the UK water industry: A review. J. Water Process. Eng. 2018, 21, 116-126. [CrossRef] 
10. Stankiewicz, A.I.; Moulijn, J.A. Process intensification: Transforming chemical engineering. Chem. Eng. Prog. 2000, 96, 22-34.

11. Van Gerven, T.; Stankiewicz, A. Structure, energy, synergy, time-The fundamentals of process intensification. Ind. Eng. Chem. Res. 2009, 48, 2465-2474. [CrossRef]

12. Von Münch, E.; Mayumbelo, K.M.K. Methodology to compare costs of sanitation options for low-income peri-urban areas in Lusaka, Zambia. Water SA 2007, 33, 593-602.

13. Kvarnström, E.; McConville, J.; Bracken, P.; Johansson, M.; Fogde, M. The sanitation ladder-a need for a revamp? J. Water Sanit. Hyg. Dev. 2011, 1, 3-12. [CrossRef]

14. Katukiza, A.Y.; Ronteltap, M.; Niwagaba, C.B.; Foppen, J.W.A.; Kansiime, F.P.N.L.; Lens, P.N.L. Sustainable sanitation technology options for urban slums. Biotechnol. Adv. 2012, 964-978. [CrossRef] [PubMed]

15. Van Dijk, M.P.; Etajak, S.; Mwalwega, B.; Ssempebwa, J. Financing sanitation and cost recovery in the slums of Dar es Salaam and Kampala. Habitat Int. 2014, 43, 206-213. [CrossRef]

16. Lutze, P.; Gani, R.; Woodley, J.M. Process intensification: A perspective on process synthesis. Chem. Eng. Process. Process. Intensif. 2010, 49, 547-558. [CrossRef]

17. Qiu, Z.; Zhao, L.; Weatherley, L. Process intensification technologies in continuous biodiesel production. Chem. Eng. Process. Process. Intensif. 2010, 49, 323-330. [CrossRef]

18. Rao, D.P.; Bhowal, A.; Goswami, P.S. Process intensification in rotating packed beds (HIGEE): An appraisal. Ind. Eng. Chem. Res. 2004, 43, 1150-1162. [CrossRef]

19. Drioli, E.; Stankiewicz, A.I.; Macedonio, F. Membrane engineering in process intensification-An overview. J. Membr. Sci. 2011, 380, 1-8. [CrossRef]

20. Pekdemir, T.; Keskinler, B.; Yildiz, E.; Akay, G. Process intensification in wastewater treatment: Ferrous iron removal by a sustainable membrane bioreactor system. J. Chem. Technol. Biotechnol. 2003, 78, 773-780. [CrossRef]

21. Keskinler, B.; Akay, G.; Pekdemir, T.; Yildiz, E.; Nuhoglu, A. Process intensification in wastewater treatment: Oxygen transfer characterisation of a jet loop reactor for aerobic biological wastewater treatment. Int. J. Environ. Technol. Manag. 2004, 4, 220-235. [CrossRef]

22. Seck, A.; Gold, M.; Niang, S.; Mbéguéré, M.; Diop, C.; Strande, L. Faecal sludge drying beds: Increasing drying rates for fuel resource recovery in Sub-Saharan Africa. J. Water Sanit. Hyg. Dev. 2015, 5, 72-80. [CrossRef]

23. Gold, M.; Dayer, P.; Faye, M.C.A.S.; Clair, G.; Seck, A.; Niang, S.; Morgenroth, E.; Strande, L. Locally produced natural conditioners for dewatering of faecal sludge. Environ. Technol. 2016, 37, 2802-2814. [CrossRef]

24. Sitter, S.; Chen, Q.; Grossmann, I.E. An overview of process intensification methods. Curr. Opin. Chem. Eng. 2019. [CrossRef]

25. World Health Organization. Guidelines for the Safe Use of Wastewater, Excreta and Greywater: Excreta and Greywater Use in Agriculture; World Health Organization: Geneva, Switzerland, 2006; Volume 4.

26. UN-HABITAT. Malawi: Blantyre Urban Profile; UN-HABITAT: Nairobi, Kenya, 2011.

27. Jimenez-Cisneros, B.E.; Maya-Rendon, C.; Salgado-Velázquez, G. The elimination of helminth ova, faecal coliforms, Salmonella and protozoan cysts by various physicochemical processes in wastewater and sludge. Water Sci. Technol. 2001, 43, 179-182. [CrossRef] [PubMed]

28. Abu-Orf, M.M.; Brewster, J.; Oleszkiewicz, J.; Reimers, R.S.; Lagasse, P.; Amy, B.; Glindemann, D. Production of class A biosolids with anoxic low dose alkaline treatment and odor management. Water Sci. Technol. 2004, 49, 131-138. [CrossRef] [PubMed]

29. Greya, W.; Thole, B.; Anderson, C.; Kamwani, F.; Spit, J.; Mamani, G. Off-Site Lime Stabilisation as an Option to Treat Pit Latrine Faecal Sludge for Emergency and Existing On-Site Sanitation Systems. J. Waste Manag. 2016. [CrossRef]

30. Kalulu, K.; Thole, B.; Mkandawire., T.; Kululanga, G. Variability of the characteristics of pit latrine sludge from unplanned settlements in the cities of Malawi. Mal. J. Appl. Sci. Innov, under review.

31. Tilley, E.; Lüthi, C.; Morel, A.; Zurbrügg, C.; Schertenleib, R. Compendium of Sanitation Systems and Technologies; Swiss Federal Institute of Aquatic Science and Technology (Eawag): Dübendorf, Switzerland, 2008.

32. Still, D.A. After The Pit Latrine is Full. What then? Effective Options for Pit Latrine Management. In Proceedings of the WISA Biennial Conference, Durban, South Africa, 19-23 May 2002. 
33. Koné, D.; Cofie, O.; Zurbrügg, C.; Gallizzi, K.; Moser, D.; Drescher, S.; Strauss, M. Helminth eggs inactivation efficiency by faecal sludge dewatering and co-composting in tropical climates. Water Res. 2007, 41, 4397-4402. [CrossRef]

34. British Standard BS 1377. Methods of Test for Soils for Civil Engineering Purposes, Part 1-4; British Standards Institution: London, UK, 1990.

35. Water Research Commission. WRC 2173: Protocol for LaDePa Sludge Characterisation; Water Research Commission: Pretoria, South Africa, 2013.

36. British Standard BS 6068. Water Quality: Specification and Method of Tests; British Standards Institution (BAI): London, UK, 1995.

37. AOAC. Official Methods of Analysis of AOAC International, 17th ed.; AOAC International: Gaithersburg, MA, USA, 2000.

38. Gee, G.W.; Or, D. Particle-size analysis. Methods Soil Anal. 2002, 4, 255-293.

39. Smollen, M. Evaluation of municipal sludge drying and dewatering with respect to sludge volume reduction. Water Sci. Technol. 1990, 22, 153-161. [CrossRef]

40. Davison, L.; Bayley, M.; Kohlenberg, T.; Craven, J. Performance of Reed Beds and Single Pass sand Filters with Characterisation of Domestic Effluent: NSW North Coast; NSW Dept. of Local Government, Lismore City Council: Lismore Water, Australia, 2002.

41. Wang, L.K.; Shammas, N.K.; Hung, Y.T. Biosolids Treatment Processes; Humana Press: Totowa, NJ, USA, 2007; Volume 6.

42. Kuffour, A.R.; Awuah, E.; Sarpong, D.; Anyemedu, F.O.K.; Koné, D. Effects of different solid loading rates of faecal sludge on the dewatering performances of unplanted filter bed. Civ. Environ. Res. 2013, 3, $39-48$.

43. Kengne, I.M.; Akoa, A.; Koné, D. Recovery of biosolids from constructed wetlands used for faecal sludge dewatering in tropical regions. Environ. Sci. Technol. 2009, 43, 6816-6821. [CrossRef]

44. Niwagaba, C.; Kulabako, R.N.; Mugala, P.; Jönsson, H. Comparing microbial die-off in separately collected faeces with ash and sawdust additives. Waste Manag. 2009, 29, 2214-2219. [CrossRef] [PubMed]

45. Cofie, O.O.; Agbottah, S.; Strauss, M.; Esseku, H.; Montangero, A.; Awuah, E.; Kone, D. Solid-liquid separation of faecal sludge using drying beds in Ghana: Implications for nutrient recycling in urban agriculture. Water Res. 2006, 40, 75-82. [CrossRef] [PubMed]

46. Kuffour, R.A. Improving Faecal Sludge Dewatering Efficiency of Unplanted Drying Bed. Ph.D. Thesis, Kwame Nkrumah University of Science and Technology, Kumasi, Ghana, 2010. 